\title{
COMO "CEM HOMENS E UMA GAROTA"
}

\author{
Willy Corrêa de Oliveira
}

Compositor e Professor da ECA/USP

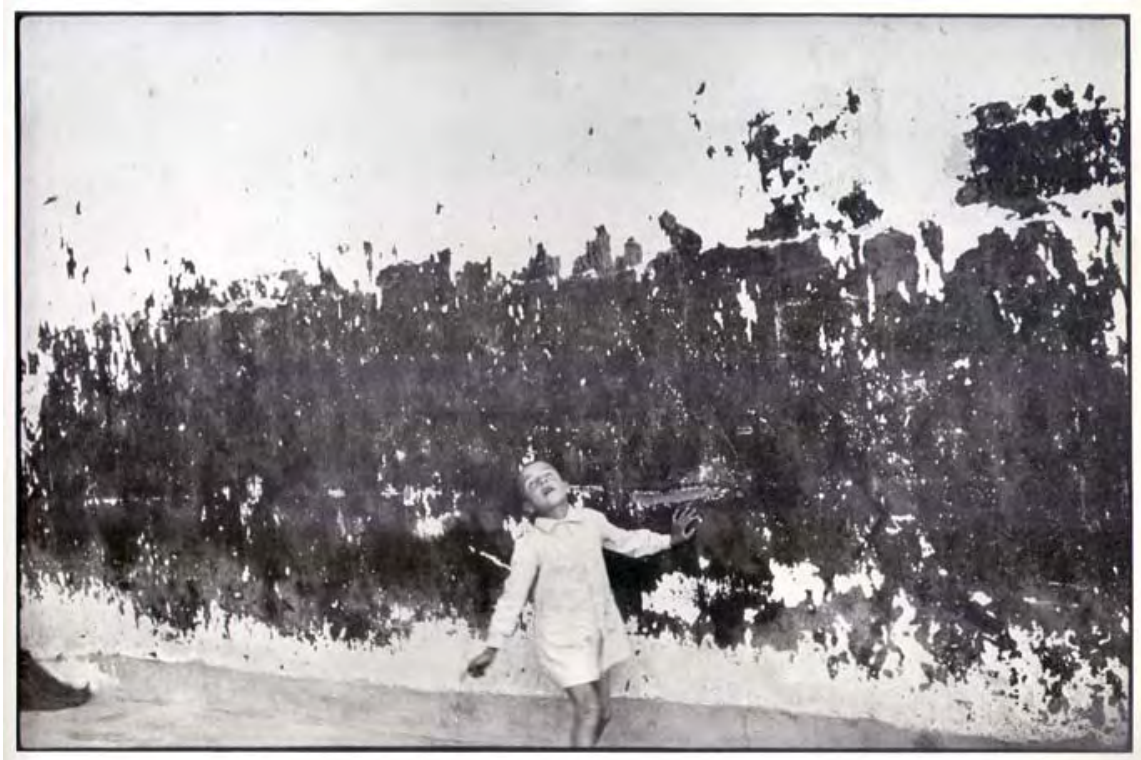

Henri Cartier-Bresson, "Valência, Espanha, 1933"

\footnotetext{
*Alusão ao título do filme “100 men and a girl” (EUA, 1936), dirigido por Henry Koster, com Deanna Durbin, Adolphe Menjou e Leopold Stokovski, em mais uma tentativa da mídia de fazer de conta que a música erudita conta na sociedade capitalista.
} 
A fotografia que encima este texto serve de pretexto para as palavras que grafo aqui. A fotografia - forte, de Cartier-Bresson - não se relaciona com este escrito, a não ser de modo longínquo, ou de nenhum modo, até. Explicome: o professor Carlos Zeron sondou-me, algum tempo atrás, sobre a possibilidade de publicar um trabalho meu que versasse sobre a conjunção MÚSICA + HISTÓRIA, para a Revista de História que vocês, agora, têm à mão. Historiadores escreveriam sobre MÚSICA e eu, músico, sobre HISTÓRIA. Fascinoume a companhia. Disse sim, pensando em oferecer-lhe um momento do meu trabalho CADERNOS ${ }^{1}$, inédito, que enfoca o tema proposto com nitidez (até onde posso enxergar). Carlos Zeron, que conhecia os Cadernos, aquiesceu. Do texto original apartei uma fração que se desobriga de acompanhar esta publicação, com vantagem, mas o restante, cedido para esta revista, inicia-se (sem mais) com a citação de uma foto de Paul Badura-Skoda estampada em jornal. Pode soar abrupto o texto começar por uma fotografia, mas a verdade é que a imagem do conhecido pianista chegando a São Paulo é mais eloqüente do que mil textos dizendo sobre História + Música. Mais veemente do que estantes e mais estantes cheias de livros nunca disseram. Concluído este parágrafo, detenham-se - por favor - na fotografia seguinte. Ela deve ser examinada, auscultada e motivo para reflexões antes de prosseguir texto afora. Obrigado.

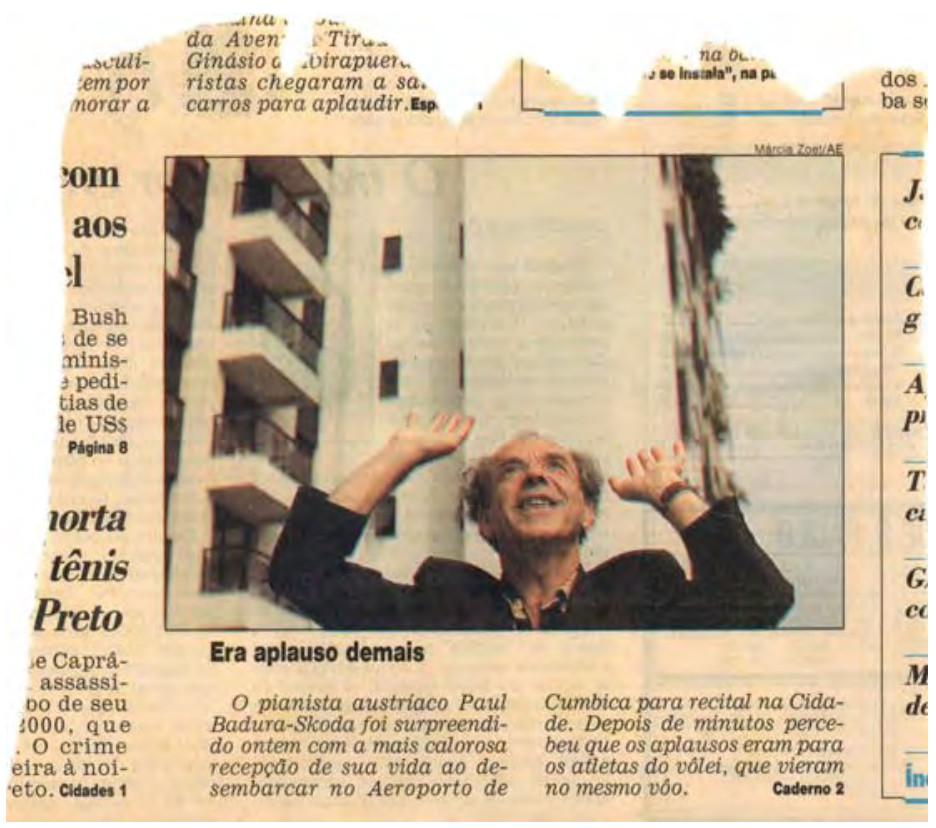


Não deveria surpreender que Badura-Skoda não era o alvo dos aplausos. Coisas assim são corriqueiras em Mahagonny ${ }^{2}$. No entanto, para as palmas que ainda continuam fragorosas na legenda da fotografia do recorte de jornal, não são exigidas inteligências que ultrapassem o limite mais mínimo possível de reduzidas potencialidades. Importa, oportunamente, que a coordenação motora esteja incólume. É contra-indicado que uma palma se desencontre da outra; que o rosto do aplaudidor seja atingido pelas costas da mão de seu vizinho de aplausos. Mesmo que pancadas mais fortes já tenham sido desferidas em acontecimentos desportivos. Assassinatos, até. Em Mahagonny.

De volta à fotografia de Badura-Skoda estampada no jornal: regras de vôlei são facilmente assimiláveis, em instantes. Por outro lado, não é nossa intenção mascarar o fato de que o pianista tenha se mostrado bastante ingênuo para se ver assim aplaudido no atual estágio conquistado pelo capitalismo.

Que mais se escuta em Mahagonny além de aplausos?

De música erudita, certamente, muito pouco: quase nada. Para que se tenha idéia concreta: "Decorridos 15 anos da globalização do CD, a produção de música erudita está em torno dos 3,8\%, em todo o mundo”3. Não obstante tenhamos demonstrado renovadas capacidades de aplausos para, por exemplo, regalar os Três Tenores, e celebrar Jessie Norman, em eventos esportivos vários, em comemorações centenárias para milhões de aplaudidores. Em praça de Modena, perpetramos dantesca ovação para Pavarotti, em duetos e terceto com pop-singers; feericamente iluminados e difundidos para as antenas de TV de todo o mundo. Temos sido capazes de tudo isso.

De tudo isso temos sido capazes; e nada impede que a situação da música erudita no capitalismo continue lamentável. Três vírgula oito por cento, abarcando toda a História da música ocidental, dos primórdios aos nossos dias, sem o possível engano de que as exíguas cifras estivessem indicando somente a música contemporânea. Imagine-se o gigantismo do sumário que esses três vírgula oito por cento perfazem: incluídos os gêneros, estilos, mídia, de

\footnotetext{
${ }^{1}$ Cadernos, tese de doutoramento apresentada ao Departamento de Música da Escola de Comunicações e Artes da Universidade de São Paulo em 1998. Jaz em uma das estantes da biblioteca da ECA.

${ }^{2}$ Alusão a "Aufstieg und Fall der Stadt Mahagonny” (“Ascensão e queda da cidade de Mahagonny”), ópera política satírica composta por Kurt Weill a partir de um libreto de Bertolt Brecht. Estreou no dia 9 de março de 1930 em Leipzig [nota do editor].
} 
todos os períodos históricos. Ainda as salas de concertos vazias, a indigente vicissitude da arte, a situação estupidificante dos artistas.

Os resultados conseguidos com os concertos para grandes massas, em praça pública, com posologia cientificamente administrada de porções de "música clássica”, "semi-clássica” e "popular” não surtiram o efeito desejado, até agora. E constate-se que tal prática já estava em voga nos EE.UU. desde o início do século. Os diversos intentos de concertos-educativos tampouco lograram uma educação musical razoável para a assistência. Tem explicação. O problema básico é que a sintaxe musical não é simples como as regras de uma partida de vôlei. Requer disciplinadíssima busca teleológica e, hoje mais que jamais, rigor na periodização, dedicação e tempo necessários para a educação desejada. Até os dias atuais, o sistema capitalista não deu mostras de sensibilidade musical compatível com a realização da MÚSICA como LINGUAGEM. Como enriquecimento espiritual do homem. Da música como arte, como testemunho da capacidade criadora do homem. Não se pode colocar a questão da educação, conhecimento e comunicação musicais, sem a inclusão de um dado fundamental para a montagem da equação: o modo de produção capitalista. "Na sociedade capitalista, já dissemos, o trabalho humano tem por finalidade a acumulação de capital. Para que um capital cresça, é necessário vendê-lo,

\footnotetext{
3 “A produção mundial de música erudita, que até a década de 80 não passava de $1.5 \%$ do total de discos prensados por toda indústria fonográfica, saltou, nos primeiros anos da década de 90 para 3.8\%. Deve-se levar em conta que o principal fator que desencadeou essa modificação estatística, independente do gosto do chamado consumidor, foi um câmbio tecnológico fundamental: a substituição dos processos de reprodução e gravação de som, antes mecânicos, pelos digitais. Ainda assim, deve ser levado em conta que a classificação “música erudita”, aceita pelas gravadoras no mundo inteiro, está longe de consagrar o purismo do gênero (também denominado clássico). Isto porque, entre os 3.8\% compreende-se também um conjunto de dados que não correspondem, necessariamente, ao “clássico”. São, muitas vezes, canções folclóricas germânicas, nórdicas ou eslavas, em outras composições religiosas - que, executadas por orquestras tradicionais, passam a figurar nos catálogos como "música erudita”. Também devem ser depurados aos títulos de discos e álbuns, denominados de "trilhas”, que arremedam, mediante cópia do modelo dos antigos LP's de vinil, a coletânea de faixas breves, de movimentos extraídos aleatoriamente de diversas peças conhecidas. Tudo isto para dizer que, nem os 3.8\% expressam um dado confiável, nem indicam um valor que represente a magnitude de um mercado que mereceria mais do que, simplesmente, figurar numa tabela de mercado ao lado dos pomposos 64\% de música POP”. Comentário de Tupã G. Correa à intervenção de Bob Johnston, diretor comercial da EMI Internacional no "Symposium on World Market of Music” - Nashville, Tennesse, USA, October, from 14 to 17, 1994. T.G. Correa é estudioso do Mercado Fonográfico, autor de Rock, nos Passos da Moda. Campinas: Papirus, 1989.
} 
então, é preciso que o trabalho humano sirva para produzir bens de consumo. Já observamos que é aí que se encontra, segundo nossa opinião, o vício fundamental deste tipo de economia. Assim podemos afirmar, sem medo de possível engano, que o papel do homem na terra não consiste, ou pelo menos, consiste cada vez menos e menos, na produção exclusiva de bens de consumo"*4. Porém, no capitalismo, todas as questões, inclusive as questões culturais, obedecem à lógica do sistema, ao mercado.

O mercado não é simplesmente o lugar onde se comerciam gêneros alimentícios e outras mercadorias. Mais de que isso. Não é apenas a relação estabelecida entre oferta e procura de bens e/ou serviços e/ou capitais. E não só nomeia grupo de pessoas e/ou empresas que, oferecendo ou buscando bens e/ou serviços e/ou capitais, determinam o aparecimento e condições dessa relação. O mercado dispõe de força e autoridade e delibera e age e obriga. O mercado é soberano, autoritário, exerce força e influência sobre a tua vida, a minha vida. Decide os destinos. Mas convém lembrar que o mercado não é um ente abstrato, como um dragão que se aloja em satélite inatingível onde só um santo tem o poder de lanceá-lo. O mercado é manipulado por homens. Homens que enriquecem e, com base na riqueza, tornam-se poderosos: o mercado!

O desenvolvimento espiritual do homem não encontra, por força da própria estrutura e dinâmica do sistema, condições favoráveis à sua maturação. O pecado capital, em Mahagonny, é não ter capital. Tudo o que não estiver centrado nesse mister, apresenta-se - forçosamente - como desvio, ou até mesmo como óbice. “Time is MONEY”. Urge. Quem com o capital não ajunta, espalha. Para acumular capital não se faz necessário desenvolvimento espiritual. A frase anterior poderia servir de legenda para as fotografias de, por exemplo, Béla Bartók e Sílvio Santos, postas lado a lado. E de quantos outros pares de fotografias o leitor não disporia?

"O antigo possuidor de dinheiro marcha adiante como capitalista, segue-o o possuidor de força de trabalho como seu trabalhador; um, cheio de importância, sorriso satisfeito e ávido por negócios; o outro, tímido,

\footnotetext{
${ }^{4}$ LABORIT, Henri. Biologie et Structure. Collection Folio-Essais. Paris: Gallimard, 1968, p. 121-122.
} 
contrafeito, como alguém que levou sua própria pele para o mercado e agora não tem mais nada a esperar, exceto o - curtume" ${ }^{5}$.

Um, sorridente, o dono do curtume, ávido de negócios, o outro levando a própria pele para o mercado: onde, como, em meio a esta estrutura, o desenvolvimento do espírito? Vaguíssimo simulacro de desenvolvimento do espírito pode estar sendo partilhado por outros que alugam para o dono do curtume, a cabeça. De tudo se leva para o mercado: sexo, músculos em negócios olímpicos, gargantas.

Tornemos às cabeças. Afinal de contas é necessário que alguém projete palácios para os donos do curtume e casas populares para os que levam a própria pele para o mercado. Ao relento não podem ficar: posto que prejudicaria o acúmulo de capital. É preciso que alguns façam músicas que distraiam - em especial - os que deixam a própria pele no curtume, porque para o dono do curtume pode ser bastante mavioso: o tilintar de suas moedas. De alguma maneira, música é indispensável. Os esfolados podem um dia se insurgir contra a idéia de serem obrigados à venda de peles para dono de curtume. Isso prejudicaria o acúmulo de capital. Um mínimo, pois, de desenvolvimento do espírito é indispensável, para que os arquitetos projetem diferentes abrigos contra o sol, o vento, o frio e a chuva; para que os músicos distraiam o povo; para que letras sejam aprendidas e depois estocadas em livros que glorifiquem o acúmulo de capital. Ou até mesmo que não o acusem de atividade inglória. Um pouco de espírito é, sim, vantajoso, para que o acumulador de capital seja representado em esculturas; assim como aqueles que o auxiliaram, e alguns escolhidos a dedo, dentre os que não tenham estorvado, (podem ser “exemplares”). E quadros são necessários. Quadros caros, cujos preços sejam tão eloqüentes que dispensem o desenvolvimento espiritual que seria necessário para a sua apreciação. E ciência também. Ciência que facilite o acúmulo de capital. Mesmo medicina: posto que, até pouquíssimo tempo, alguém que leva a própria pele para o mercado não deveria prejudicar o dono do curtume com sua morte prematura.

E há ainda em Mahagonny, poetas, músicos, artistas de toda sorte que escrevem para si próprios: trabalham para o dono do curtume em outras atividades, em outras horas; nas "horas vagas” é que praticam suas artes. E, mui-

${ }^{5}$ MARX, Karl (Victor Civita Ed.). O Capital. (Tradução de Régis Barbosa e Flávio R. Kothe). Volume I, tomo I, $3^{\text {a }}$ edição. São Paulo, 1988, p. 141. 
to provavelmente porque dispõem dos privilégios de horas vazias - e de outras comodidades mais em consonância com elas - é que suas artes, em tais horas, não colidem com a idéia básica do curtume. Com o cheiro que dele emana. Isso, possivelmente, dá a ilusão de que o espírito cresce em volta do curtume. Em meio à carnificina, é necessária a “imagem” de que o curtume promove o espírito.

Um quadro, uma escultura, ainda podem se valer de altos preços no mercado, mas a música erudita, não sendo objeto único e silenciosa mercadoria, não conquistou boa paga. O pouco de música erudita que se transformou em mercadoria, faz exigências muito elevadas. Adaptável (com docilidade) só para colecionadores; como itens de decoração. Para o consumo de música do passado, o ouvinte carece de preparação histórica e técnica que o habilite a decodificar aquilo que ele escuta. Há que situar a obra em seu contexto sócio-cultural; compreender o sistema de referência, de organização do material musical, do qual a obra é expressão; as inter-relações de ordem morfológica; ter o conhecimento e a freqüentação às obras que possibilite ao ouvinte a distinção idioletal; consciência (no plano mesmo da composição) dos parâmetros do som e suas potencialidades lingüísticas. De outro modo, aquilo que ele ouve é apenas uma manifestação acústica, sem muito mais. Como trovão ou abalroamento de automóveis. Mais agradável, na maioria das vezes, mas não o suficiente para que se preencham as necessidades do espírito. Outrossim, a produção fonográfica de música erudita não estaria por volta dos 3,8\%, em todo o mundo, hoje.

E assinale-se que não mencionei a música escrita no presente. Logo mais abordaremos esta anomalia crucial.

A situação deplorável da música erudita em torno do curtume não é conseqüência, apenas, de sua forma de apresentação (de fato ridícula), como muitos assinalam. "Muito chato, roupa preta, muito imóvel; o jovem hoje quer dinamismo, coisa rápida”, isto ouvi dizer. “A música erudita tem que se adequar ao que os jovens querem; o pessoal de baixa renda etc.”: isto significa que teríamos de ajustar, de proporcionar o pensamento musical à capitalística jovem insipiência. Não consigo enxergar como isso seria possível. E tanto não é que, mesmo com a sintonia entre a ignorância e a trampolinagem da indústria cultural, a produção de música erudita continua decrescente e chega nos dias de hoje, no cômputo da indústria fonográfica mundial, à cifra de 3,8\%. Mesmo levando-se em conta o estrondo dos aplausos em praças públicas e estádios, devidamente assessorados pelas mídias. 
“Não precisa ser chato para ser sério”, ouvi de um amigo. E respondi-lhe: o problema não está na chatura da seriedade, mas na ignorância estrutural que faz corpo com o sistema de organização econômico e, conseqüentemente, na cultura que engendra e formata. O problema continua a desafiar as "soluções" perpetradas nas cercanias do curtume. "Qual o formato que melhor encaixaria a música erudita?” A questão não está em formatos e encaixes.

Quanto custa uma educação musical que prepare, de fato, adestre, habilite alguém a envolver-se com a linguagem musical erudita a partir de uma sintaxe e semântica específicas?

Difícil responder a uma pergunta que implica número expressivo de variáveis - no capitalismo - como: o poder aquisitivo e custo de manutenção do educando, a disponibilidade de tempo de dedicação aos estudos, possibilidades de freqüentação das obras musicais, abrangência das relações inter-disciplinares, exeqüibilidade dos materiais didáticos necessários. Também entram em jogo a habilitação e a habilidade pedagógica do professor - no caso que nos ocupa - de língua que não se fala mais.

Em condições ideais, o custo varia entre 350,00 a 600,00 reais por mês. Previstos programas de alfabetização musical preparatória, a sintaxe dos diversos sistemas de referência, morfologia, história. Inicialmente cerca de uma hora semanal, passando depois dos alicerces teóricos para três a quatro horas-aula semanais, durante aproximadamente quatro e cinco anos. "Como os filhos, investimento sem retorno”, segundo afirmação de um aplicado, vetusto, cliente de supermercado de "zona nobre” da cidade de São Paulo. E o resto não é silêncio. Barulhos.

Alaridos, estrépitos, estrondos, estrupícios, estupros, furdúncios, seríbolas, ingresias. Gritos! Desordem e regresso. Gritos de dores dos esfolamentos de peles vêm do curtume, toldadas em graviolências de putrefações. Necessitase, em Mahagonny, de música de mascarar clamores. E há. Passam de 100dB s.p.l. até quase o limiar da dor. De léxico trivial, de fácil assimilação - inculcadas através das mídias -; as invenções nessas músicas são arriscadas com o mesmo rigor com que a obsolescência planejada é fixada para qualquer mercadoria de moda. Vale, fundamentalmente, pela eficácia no abafamento dos gritos de dor das despelações. Muito barulho por tudo. Sobretudo importa que o que sobre de espírito, aniquilado, não anseie pelo que ainda possa fremir entre o coração estropiado e a mente dopada. Existem, outrossim, preferências por canções que entorpeçam mais suavemente, com "letras” mais cuidadas para 
clientela mais esclarecida - embora, organicamente, em sintonia com as antenas de Mahagonny. Porém, a violência é, no geral, bem mais utilizada. Na dialética MATÉRIA/ESPÍRITO, no capitalismo atual, a matéria já se polarizou e, em seu bojo congrega a violência. Matérias da violência: modo de produção: modo como os homens competem, como concertam suas violências, consumos, seus lixos imperecíveis ${ }^{6}$. Angústias amplificadas até quase o limiar da dor. O espírito entorpecido: o EGO crescendo como um câncer, insaciável, consumindo mais e mais até à intumescência ingluvial. Consumindo-se. Como asseverou o Dr. Oswaldo Menendez: "De mim não sai mais nada, só entra”. O exercício de sua "natureza de compradores profissionais em tempo integral”. Desgraçadamente válido também para os que deixam no curtume a própria pele $^{7}$, como para os que alugam a cabeça, ou outros órgãos. Dores. Limiar da dor. 120 dB s.p.l. Não há umbral para a dor de cada pele esfolada: sendo cada dor, uma e uma só. Inatingível pela dor vizinha, tal a desordem, o fragor, o ruído de fundo, insuportáveis. $120 \mathrm{~dB}$ s.p.l. Cada um dos aflitos tem, em Mahagonny, a LIBERDADE de ter a sua própria e única dor, personalizada. Individualizada como prega a raiz da ideologia que se propaga em Mahagonny.

Subsiste, também, uma música erudita contemporânea em Mahagonny. De pasmar: não é língua viva, mínimo o uso que se faz dela, e, todavia, persiste. Entes que em suas horas de ócio, destes de quem suas peles raramente afastam-se de seus ossos, aproximam-se dela. Geralmente estão envolvidos em fazê-la. Nas horas de ócio, como disse, pois por ofício alugam a cabeça para prestações de outros tipos de serviços, ao dono do curtume; vendem, por vezes, as almas: logradas por fáusticas ilusões. Mas lucram, por outro lado, de horas vagas, peles sedosas, intactas, mãos macias, nascidas para as penas de escrever. Nunca têm, como afirmou Brecht, as mãos sujas de sangue.

\footnotetext{
6 “... o sucesso social numa sociedade mercantil não exprime, na maioria das vezes, senão a aptidão para explorar seus semelhantes, de acordo com as regras que esta sociedade estabeleceu para sua própria segurança. Não é mais o urso que o homem encontra à saída da caverna moderna, mas o patrão, o superior hierárquico, as leis sociais, as relações de produção, o “outro”, sob todas essas formas.” LABORIT, Henri. L'A gressivité Détournée. Collection 10-18. Paris: Union Générale d’Éditions, 1970, p. 152 e 79. "Não será a propriedade individual das coisas e dos seres - a qual, é fácil mostrar, não passa do resultado de uma aprendizagem, de um automatismo cultural - que provoca como resposta a agressividade?” LABORIT, Henri. Deus não joga dados. Tradução de Maria da Silva Cravo. São Paulo: Trajetória Cultural - Divisão Editorial da Grano EPC Ltda., 1988, p. 134.
} 
Comem a carne, sim, mas as sujeiras de sangue são deixadas para os açougueiros. Limpos e alimentados, sonham alto, por vezes figuram-se até como vencedores de Mephisto.

"É o mundo moderno que quer assim. Criou-se uma verdadeira casta - os intelectuais - que tem a incumbência de pensar, e que para isto submetem-se a um treinamento especial. São constrangidos a alugarem suas cabeças a patrões, como nós, nossos braços. Naturalmente eles têm a impressão de que pensam para a coletividade; mas é tudo como se nós achássemos que fabricamos automóveis para a coletividade - nunca iremos acreditar nisso, bem sabemos que é para os patrões. Que nos deixem em paz com essa estória de coletividade”, disse Kalle ${ }^{8}$ - operário metalúrgico.

Muitas vezes ouvimos a pecha de elitista alvejada contra a música erudita contemporânea. Incorreta. Improvável que a música erudita que se faz hoje tenha primazia no gosto da elite proprietária do curtume. Dono de curtume não curte essa música; peles, o tempo todo, e para passar o tempo, coisas reles, geralmente. Música erudita contemporânea não é opção, nem mesmo da “casta de intelectuais”; nem mesmo de músicos: profissionais ou amadores. Reduzidíssimo o grupo de pessoas que tem o hábito de escutar algumas das variedades de música erudita escrita na atualidade. Elitista não é, seguramente, embora circulem - em média - entre algumas das pessoas que desfrutam de ócios, cujas peles não são expressamente utilizadas para os negócios do curtume. Porém é tão minimamente que circula, a música contemporânea, se é que circular é verbo adequado; menos ainda compreender, seria. Por isso preferi o termo circulação - com a devida ressalva de que é pouca. Compreender a música, hoje, não é empreitada das mais possíveis.

Em primeiro lugar porque não se trata de uma língua, a que se trata de compreender, mas de tantas. Tão díspares, opostas, várias, inviáveis quantas. Algo próximo da idéia de uma Babel construída no pátio de uma casa de orates. Contíguo ao pátio, o patético panteão dos construtores da torre exibe, entre

\footnotetext{
7 “Ao trabalhador lhe é concedido que tenha só de que viver e queira viver só para ter”. MARX, Karl. Oekonomisch - Philosophische Manuskripte, p. 144. MARX, Karl. Manuscritos Econômico-Filosóficos, (seleção de José Arthur Gianotti), tradução de José Carlos Bruni para o vol. XXXV de Os Pensadores, São Paulo: Abril S.A. Cultural e Industrial, 1974.

${ }^{8}$ BRECHT, Bertold. Diálogos de Exilados (Flüchtlingsgesprãche). Frankfurt, Alemanha: Surkamp Verlag, 1961 (Prosa 2, constitui o tomo VI das GESAMMELTE WERKE).
} 
inúmeros outros: Schöenberg (dodecafônico), Strawinsky (ainda neo-clássico, como representado no busto do nicho à direita), Cage, Carter, Britten, Webern, Milhaud, Stockhausen (ensaiando “Aus den sieben tagen”), Kagel, Xenakis, Schaeffer, Paik, Schnebel, Hindemith, Boulez. Outros, outros. E a partir do quarto, quinto escalão, escotoma à vista, ar irrespirável, começa a galeria dos balbuciadores de imitações. Língua falada, nenhuma chegou a ser em qualquer distrito de Mahagonny. Menos ainda a parvoíce de julgamentos (freqüentes) de uns sobre os outros: há.

Discursos de loucos. Como fala de loucos. Falar como falam certos alienados, o fardo do criador musical mahagonnês. Como pessoas, aos magotes, já andam falando e gesticulando sós pelas cidades. Nem é raro que alguém reaja à abordagem de desconhecido, fugindo às pressas, fingindo não ter sido interpelado.

Conheci alguns doudos que me impressionaram. Lembro-me de um que se dizia Napoléon, a mão enfiada entre os botões abertos da camisa, contava de vitórias, e chegava às lágrimas quando narrava sobre Waterloo e os dias de Santa Helena, com detalhes exuberantes. Outro, conhecido por Avião, apaixonado por cinema americano, desdenhava de qualquer produção em outra língua. Tinha, pregados ao chapéu de palha, figuras de artistas e ilustrações dos ambientes onde o filme acontecia. Narrava a estória apontando para as imagens afixadas no chapéu, acompanhando-as com sons onomatopaicos e imaginativas imitações de palavras inglesas. Em cenas de aviação, é até hoje, inigualável. Entre seus filmes, sempre exibidos através de estampas aplicadas no chapéu de palha, a sonoplastia impecável, havia um "musical”, cujo enredo era interrompido (volta e meia) pela canção que utilizava a melodia de Bésame mucho $^{9}$, com esta letra, em seu inglês pessoal:

BÊZAME BÊZAMEMUTCH
MELOLIBLORI LI BLIS
PLÁU CI PLÁU Cl
BÊZAME BÊZAMEMUCTH
MELO LI BLORI LI BLIS SHEURIÔ! ${ }^{10}$

A música deste século em Mahagonny tem a aparência de arengas de loucos. A lógica não é partilhada pelo grupo, mas expressão congruente apenas

${ }^{9}$ De Consuelo Velasquez.

${ }^{10}$ Cantava estas palavras atropeladamente de modo quase a torná-las indistintas, talvez porque suspeitasse que não eram norte-americanas, de fato. 
com a realidade psíquica do compositor. Terreno fertilíssimo para pesquisas psicomusicológicas, sociais, para a identificação patológica do paciente-compositor, através de obras, de conjuntos de obras, a serem catalogadas como:

\section{NEUROSE \\ PSICOSE \\ emesmo PERVERSÕES.}

Há toda espécie de moléstias da mente, do espírito, na música atual, sob o capitalismo dominante. Que não se estranhe o que não é estranho.

Não há língua viva, falada (considerando-se a música erudita), em Mahagonny. Só na música pop encontra-se algo próximo desta função. E como já apontamos em abordagens anteriores, o sistema (através do trabalho das mídias, do embrutecimento do espírito, em conluio com a ignorância que faz corpo com a atividade de compradores profissionais em tempo integral) incentiva e divulga e inculca esse modo de falar-mercadoria que se torna comum, simulacro de língua única da tribo. O músico erudito, condenado ao insulamento e imbuído da ilusória consciência de "genialidade" que a ideologia fomenta, vê-se obrigado a inventar - a criar-se - uma língua, ou a imitar arremedos, e, por força da insólita situação, a acreditar na proeminência da maneira que encontrou para a sobrevivência de seus anseios de linguagem. Passa a erigir em sistema sua realidade psíquica, assim isolado do grupo, movido pela carência de linguagem mais apropriada para as sofreguidões espirituais, fora da realidade tangível, e em estado de angústia que possivelmente lhe escapa.

Tal o estado das coisas, que o resultado conseguido na música capitalista atinge dois impasses:

I) Semelhante a discurso de louco, a língua alcançada pela imaginação do solitário compositor, é fruto de uma realidade só dele; sorte de declaração de ego-explícito, não tem, necessariamente, que ser compreendida e aceita pelo grupo. E não tem sido. Vez ou outra, auxiliado pela mídia, consegue alguma notoriedade e um designativo de "gênio". Sem que se possa ir mais além, não se pode provar nada com isso. Não afloro aqui - nem de leve - a tecla escorregadia do gosto pessoal. Ainda mais que acabo de chegar da belíssima exposição A vanguarda no Uruguai: Barradas e Torres-García, no Museu de Arte Moderna de São Paulo.

II) O compositor do século XX, acomodado às sobras do séc. XIX, sem se valer - obviamente - da força vivificadora de língua viva, dos tempos de 
sua vigência: de quando era um todo, e não restos. Regra geral, ouvimos colchas-de-retalhos-de-frases-feitas que o satisfeito compositor - de imaginação frugal a ponto de causar dó - exibe, com sorriso escancarado, como se fossem originais. O mesmo automatismo vivido no campo da moral, do classismo, do racismo? Não à toa, essa música é substituível pela música de mercado, com vantagens, posto que a música pop por seu uso social efetivo abre-se mais à movimentação das contradições, às sínteses. E obrigamo-nos à constatação de que a música pop é mais assimilável, mais transparentemente ligada à realidade da qual emana, e, no geral, menos enfadonha. As músicas eruditas do presente, com imprecisos contornos (fantasmagóricos) de música do passado, são desmesuradamente longas e cansativas, dado que, o tempo musical atingido pelas obras de grande alento no séc. XIX, incompreendidas pelo compositor moderno, é aplicado a materiais musicais incompatíveis. Em vez de desenvolvimento: desentendimentos, repetições injustificadas de assuntos temáticos banais, repisados com insistência durante a peça, através de pensamentos composicionais incongruentes. Em suma: sem a direcionalidade que o sistema tonal - em sua inteireza - propiciou. Não é estranho que tal músico seja insuportável. Por outro lado, a justaposição infinda de figuras sonoras dissonantes, irrepetíveis, próprias de trabalhos inspirados pela Escola de Viena, torna-se igualmente banal e enfastiante, pelo excesso de informação e amnésia presentes nos trabalhos dessa índole estética.

A discussão da música erudita capitalista, que tem sua unidade na ausência de língua viva (falada pelo grupo), leva-nos, forçosamente, à consideração de outro aspecto - além dos impasses acima considerados, que se mostra também como um certo princípio unificador do conjunto de suas diversidades: a vocação metalingüística. Sinais restantes de coisas idas. Em lugar de língua viva, comum ao grupo, metalinguagens (individualizadas), a comentar, a criticar, a refletir sobre aspecto/s de linguagem-objeto operante na História. A música do século XX remete-nos, quase sempre, a falas de tempos de língua viva.

É porque não há língua comum, e porque os compositores de música erudita, no capitalismo, não suportariam a condenação ao silêncio impenitente, que se arrojam às metalinguagens. Metalinguagem - como é sabido - é a linguagem usada por um observador para falar sobre uma linguagem-objeto. A linguagem que se volta para a linguagem. E ocorre, por vezes, que a linguagem se debruça sobre si mesma e alcança-se até como processo criativo, quando 
em tais circunstâncias, o que está em jogo é o próprio modo de jogo. A linguagem da qual se fala é a linguagem-objeto.

E porque não há língua é que a linguagem-objeto se faz essencial, necessária como signo do real, índice Histórico, resíduos de realidade, palpável, a palpitar através da metalinguagem. Como anseio de realidade. Como sonho em busca de uma realidade que a própria realidade nega, aliena.

É porque não há língua musical erudita no capitalismo, que os discursos ousados mostram-se como vestígios (evidentes ou embuçados) de idioletos, de sintaxes inteiras de épocas pregressas. Os compositores, com maior ou menor ânsia de invenção, remanejam memórias, resquícios lingüísticos: em metalinguagens. Desde Mahler, a metalinguagem instala-se em lugar da língua. De feição e meneios copiosamente declarados nas diversas “maneiras” de um Stravinsky, até ao emascaramento provocado pela novidade da alocução weberniana, a metalinguagem transborda em lugar de língua precisa. Ocorre mesmo de um determinado idioleto, com sua idiofonia imperiosa, ser tomado de empréstimo por inteiro, com gestualidade e sotaque de alguém que - concretamente - falou no passado. Tristíssimo: pois metalinguagem não deveria confundir-se com linguagem-objeto. Servilismo e falta de imaginação. Distante, um caso de imitação ignóbil assim, de trabalhos (preciosos) à la manière de, com que Ravel - por exemplo - elabora acuradíssimos exercícios; ou com o humor (a melancolia!) com que Satie satiriza em plena metalinguagem do gosto.

A música erudita no capitalismo torna-se o que cada compositor pensa e reflete sobre línguas que foram faladas em algum momento, em algum lugar. Há vezes em que um trato, só, é amplificado, e apenas. Há casos, ainda, em que a língua-objeto é apresentada como representação, drama, conceito, já desincumbida de sons (como a sublinhar a inexistência de língua musical): nem até de música incidental, oriunda do fosso da orquestra, nessas encenações.

Quase que em qualquer discurso, sinais de discursos havidos, sintoma dos mais aparentes na música erudita capitalista. Paramnésias, paralelismos, paralogismos, paramímias, parafasias. Citações, memórias, comentários, pastichos, paródias, paráfrases. Modos de vislumbrar realidade mais oportuna, que se pode operar do lado de dentro do texto. Do lado de fora do texto, o mundo do capital, a ausência de língua, o afastamento do público, a condenação ao silêncio frio de animal morto, teso, o arrepio, a fuga em disparada - em eriçamentos de horror - na busca de rastros do que foi vivo. Na desolação horripilante de cidade mor- 
ta, de ruas amontoadas de cadáveres semoventes; os fantasmas do passado: o que se encontra de mais vivo, de movimentos mais gráceis.

Em meio à paisagem horripilante e estéril, um ser desesperado criou um simulacro de linguagem, o dodecafonismo. Certamente o que podia haver de mais próximo de uma língua possível para tal paisagem. Uma língua que, se falada por seus habitantes, haveria de ter soado natural naquele meio. Mas foi a língua de um homem só, que se pensava portador de uma nova tábua de lei; de difícil aprendizado, díssona; a língua de um homem só.

Óbvio que os homens de Mahagonny são - homens sós. Apenas que para aglomerá-los, distraí-los, uni-los (pelo menos) como sustentáculos e defensores da paisagem hórrida, o sistema já dotou o mahagonnês (música pop) separado em dialetos próprios para as diferenças de classes, as diferenças de matizes intelectuais, para os diferenciados passos pelo mercado. Para todos e para cada um. Os que vendem a pele, os que são alijados de algum dos sentidos, os que alugam sexos, cabeças, vendilhões de almas, negociantes de órgãos, mercadorias outras. E todos cantam e podem cantar livremente a música pop mais conveniente, sem a cruenta lembrança, a cada uma das doze notas que se sucedem inexoravelmente, de que o lado de dentro da canção é tão hórrido quanto o lado de fora, onde vibram no ar poluidíssimo ${ }^{11}$ que respiram os cantos que necessitam cantar. Arnold Schöenberg, de puríssima cepa mahagonnesa, desafiou a todos a entoarem no mais legítimo mahagonnês, e foi preterido. Veio para os que eram seus - com a tábua de lei dos 12 mandamentos - e eles o rejeitaram.

Convenhamos que a música dodecafônica é de custosíssima memorização; cruelmente dissonante o tempo todo; confusa (dadas as semelhanças das linhas e das massas da dodecafonia em face à resistência mnemônica); angustiante (posto que a densidade da trama sonora vagueia sem direção, sem polarização, sem gravidade, sem tréguas para relaxamento); atordoante (devido a ininterrupto falso movimento compelido pela tensão constante); e as formas musicais, tomadas de empréstimo do passado tonal, não se acomodam ao

11 “...dos vários tipos de poluição, da agressividade inconsciente do homem com relação à biosfera, etc. Tudo isso é verdade, mas de que serve ficar repetindo se não se destacam as razões biocomportamentais e históricas que fazem com que tenhamos chegado a esse ponto? De que serve repetir, se não se mostra por que e como a COMPETIÇÃO MERCANTIL e a busca de dominação em todos os níveis são o fator primordial?” LABORIT, Henri. Deus não joga dados. Op. cit., p. 119. 
material empregado, estendendo sobre as idéias, durações mui longas, fatigantes. Mas, alas!, é de um realismo atroz.

Derivado do dodecafonismo (pela generalização da série de alturas para os demais parâmetros do som), o serialismo integral exaure as qualidades elencadas acima, até a exacerbação. Na serialização integral, os resíduos longínquos do passado - ainda discerníveis em obras de Schöenberg - são substituídos por programas matemáticos utilizados como se se tratassem de tratados ideais de composição. Para cada peça musical um programa: em lugar de língua, estruturas matemáticas. Não se pode negar a existência de formulações matemáticas dedutíveis dos modos como os sons relacionam-se em qualquer obra musical. Porém, a ordenação musical advinda inteira da matemática (que, dada a sua especificidade, é musicalmente surda), não é de seu domínio o atendimento às prerrogativas de uma linguagem que ocorre em outra área, e decorrente de um uso social exclusivo. Quando alguém busca uma música não vai à casa de um matemático para encomendá-la. A ineficácia dos novos compositores seriais evidenciou-se: quer pela falta de interesse para o ouvido musical, quer devido ao pauperismo das formulações matemáticas para a mente científica. Nem matemática curiosa para o músico, nem música apropriada para matemáticos.

A prática musical não é decisão a ser lavrada desde as quatro paredes de um escritório particular de Teoria da Música. Mas a arte da burguesia pensante desandou além de limites mínimos de um “médio" bom senso. Como as demais modalidades de música erudita capitalista, o dodecafonismo, a serialização integral são mais outros experimentos que se projetam de fora da práxis social da música para dentro da história da Cultura Burguesa. A história da música do século XX, em Mahagonny, é parte inalienável dessa história. História para contar estórias de faz-de-conta: de uma sociedade universal com música erudita, com arte, espírito, maravilhosa, técnica, como um conto de fadas.

\author{
Dodecafonismo \\ Niilismo Pop \\ Épico-epicurismo \\ Atonalismo \\ Politonalismo \\ Neo-clacissismo \\ Minimalismo
}

Música Intuitiva

Música Estocástica

Música Eletrônica

Música Concreta

Música Aleatória

Prose Music

Tape Music 


\author{
Arte dei Rumori \\ Pointillisme \\ Nacionalismo \\ Groupe des Six \\ Escola de Viena \\ Escola d'Arcueil \\ Fractal \\ Serialismo Total \\ Cubo Futurismo \\ Quadrilátero Passadismo \\ Dadaísmo \\ Exoticismo \\ Neo-folklorismo \\ Expressionismo
}

\author{
Abstracionismo \\ Once Music \\ Chance Music \\ Estruturalismo \\ Música Conceitual \\ Teatro Musical \\ Klängflächenkomposition \\ Cageism \\ Não-música \\ Computer Music \\ New Wave \\ Triangulations \\ Neo-tonal \\ Transgenikmusic
}

Que tampouco pareça estranho que um mesmo compositor componha obras híbridas como o AGON, ou que apresente fases distintas - em curto lapso e sem pressão exterior - como, por exemplo, o serialismo integral, incursões pelo Teatro Musical e até excursões interplanetárias a Sirius: a música, ainda então desconhecida em nosso mundo terreno, de Sirius.

Que não pareça estranho que um mesmo compositor passe por passos tão diversificados e contrapostos, como por passes de mágicas (dir-se-ia), e não por passos de caminhada de uma história da música vivida em conjunto, por homens de língua comum. A história da música burguesa, são páginas repassadas de justaposições de passos individualistas, como a sociedade da qual ela conta, rende, rendilha as "vantagens”. Desde Beethoven, já havia sinais de que as fases do artista viriam a ser francamente independentes das fases do público, “desenvolvendo-se” até ao desaparecimento final do próprio público... deixando, por fim, o artista a sós com suas fases. Embora ele deplore o fato de que o público não acerte os passos pelos mesmos passos que ele, o "artista”, sem se incomodar com o que se passa com o público, veloz - ultrapassa.

Ultrapassou, também, de longe, qualquer noção de gênero musical - que foi suplantada, finalmente, pela noção de gênio musical, de personalidade artística. Suficiente para causar desentendimentos. "Desconfiai do mais trivial, na aparência singelo”. E deixou de indagar - nosso artista "livre” - se a música teria outra função na sociedade, além daquela de ser apontada como produto de sua LIBERDADE individualíssima, em uma palavra: de sua "genialidade”. 


\section{Articulações / Exarticulações}

Desarvoradas naus de nãos. Sinuosidades de sins, sem cimento. Sintomas sem remates que o uso social da arte enseja. Sem horizonte de ortoepia à vista desde a nova Babel - construída de marfim - monumento de soledade e confusão de línguas e silêncios.

Em meio à babélica, estrambótica balbúrdia, imagine-se o que um cubofuturista pensa de um quadrilátero-passadista. Um abstracionista lírico de um sério-serialista. Um neo-clássico, o que diz de um dodecafônico? Sem romancice nisso. Um dodecafônico, o que grafa sobre um nacionalista? Há escritos circunscritos a isto. Figurem-se as assuadas entre pupilos da Escola de Arcueil com os uniformizados escolares da Escola de Viena. Entre-choques de discordâncias entre perfeccionistas compositores de acordes perfeitos e (imperfeitos na cordura) escritores de acordes dissonantes. Curto-circuitos entre músicos eletrônicos e músicos concretos em abstratas discussões dos anos cinqüenta. A estocada do estocástico contra o genérico aleatório? Os desentendimentos entre o bando inteiro do Grupo dos Seis e, do lado oposto da calçada, os pointillistes? Que dizer - por exemplo - de um prose-musician julgando um tape-musician? Um Klängflächenkompositor no ato de ouvir um once-musicista? Quanto ao novíssimo neo-folklórico e o novato new-wavista, a impressão causada é a de que não andam arrazoando.

Não me faço ilusões de que este fenômeno é contemporâneo, e só. Não quero fazer isso passar por dado único, simplesmente para defender uma tese. Quero assinalar que chegamos a este ponto. Há pouco mais de cem anos, a rixa, feroz, dividia as futurições dos partidários da música do futuro (Liszt, Wagner) da prosa dos prosélitos de Brahms (Joachin \& Cia). Então, ainda há possibilidade de polarização. Nos últimos tempos este caos dos últimos dias. Caos de caquexia. E a velha insistência na tecla do novo. Somos, agora, cento e muitos anos mais velhos do que éramos no século passado; românticos de cabelos ralos e brancos, de pele encarquilhada de maracujá (sem a calma), olheiras franzidas. Nos tempos da “música do futuro”, éramos bastante jovens, movidos pela energética vitalidade do crescimento, alguma inocência e certo incômodo a latejar entre a visonha do mundo visível e a visão de mundo propalada. Presentemente, quase duas vezes centenários, mais inflexivelmente individualistas, e a fomentar ainda velhos, gastíssimos temas, ad nauseam. Lengalengas da amarelada, besuntada tecla do individualismo. 
Não passamos de râncidos, deteriorados românticos senis ${ }^{12}$. Porém, cibernéticos. Românticos caquéticos, hoje, não nos damos conta de que nossa moléstia (purulenta, fétida, infecciosa), dificilmente curável, é o INDIVIDUALISMO agudo / crônico, causado pelo crescimento desordenado do EGO em um sistema de organização social em que o homem - usinado pela ideologia do lucro - é transformado em monstros consumidores profissionais. Classificado, para fins de pesquisa de mercado, em A B C D E ... etc., de acordo com o poder aquisitivo: isto é: com as infames desigualdades sociais. Em vez de combatermos a doença, temos conseguido, com algum sucesso "científico”, especialidades em paliativos para sintomas vários. Desnecessário dizer por quê. A questão do ensino do PADRE NOSSO aos vigários.

No esforço de aparentarmos menos degenerescência senil paralisante, de maquiarmos as feições de macróbios, com sorrisos de Matusaléns, posamos para polaróides ao lado de nossas máquinas novas, de última geração. Fazem figura e não aparentam as contradições: pois os que são vistos - sorridentes ao lado das máquinas, não são aqueles que trabalham submetidos a elas, nem os que perderam o emprego por causa delas.

Já nos fizemos passar por novos através da substituição do coração (famanadamente romântico) pelo cérebro atualizado, orgulho de nossa tecnologia de ponta. Continuaram os equívocos. Outras trocas foram tentadas. Ao baço já pedimos contribuição para uma esplêndida arte esplênica. Continuaram os equívocos. E a qualquer som que um dos órgãos do velho individualista faça soar, chamamos de: NOVA música. E delivramos, com urgência, para os livros de história, espécie de Guiness de nossos últimos gritos. Continuam os equívocos. Em parte, tantas buscas são desesperos de quem não se comunica. Em parte. Egos ciclópicos perpetuam-se enovelados em solidões gigantescas fuzilantes. Consciente, ou inconscientemente, temos mantido intactos o individualismo e os privilégios, e continuamos a desafinar no batido refrão de: NOVA ARTE. Ora, nova arte! Arte nova será a arte de uma sociedade nova. Não se deve por vinhos novos em odres velhos. Ora!

\footnotetext{
12 “....uma burguesia estéril e contente de si mesma é o equivalente da Lei Sálica e do Direito Divino da Realeza. Ela pode talvez ter sido útil, ou mesmo indispensável em uma época; hoje, ela encoraja a mediocridade e a inação, sentada em sua poltrona confortável da dignidade dos hábitos adquiridos”. LABORIT, Henri. Biologie et Structure. Collection Folio Essais. Paris: Édition Gallimard, 1968, p. 167.
} 
Não há limite, hoje, para o egoísmo, a egolatria, o ridículo. A perversão de tantos exibicionismos passa, praticamente, despercebida. Imbuídos de competitividade (como se se tratasse da única força capaz de por em movimento o "progresso" humano) e inspirados pelo poder vivificante do dinheiro (o transformador e modificador de todas as coisas), temos logrado o abafamento da ânsia e carência do sentimento de solidariedade ${ }^{13}$. Uma rápida vista de olhos (irritados pela poluição ambiental) é suficiente para avaliarmos o estado degenere do mundo que edificamos com o capital.

Mas o homem não é redutível - definitivamente, pelo menos - ao homúnculo de que o capitalismo necessita para a adoração, delirante, do Bezerro de Ouro; isto quer dizer, em profundidade, submissão aos donos do Bezerro de Ouro, que se fazem apreender, apenas, como sacerdotes. Queira ou não queira o MERCADO, o homem é ao mesmo tempo um ser individual e um ser social indivisível como uma folha de papel. Por mais que sua essência social venha sendo canalizada para as passeatas em Shoppings, Feiras e Supermercados, e desviados para concentrações fascistas, irmanados pela universal hebetude das telas de TV, por mais que ricos e pobres estejam unificados pela aspiração à riqueza, mesmo assim o homem continua - angustiadamente - a ser um ser individual e coletivo a um só tempo. Apesar de que morre à míngua o seu ser social.

Há um domínio do individual e um domínio do coletivo. Há coisas que a gente só faz só. Mesmo música, algumas vezes. Mas as práticas do domínio coletivo exigem solidariedade, altruísmo, magnanimidade; tais qualidades: sufocadas, reprimidas pelo catecismo do MERCADO divinizado, põem em risco o ser por inteiro. Não quererei esperar para ver o alvoroço derradeiro, do último alento do eu coletivo.

"Levou-o ainda o diabo a um monte muito alto, mostrou-lhe todos os reinos do mundo e a glória deles e lhe disse: tudo isto te darei se, prostrado, me adorares" ${ }^{14}$.

\footnotetext{
13 “Joana: - E porque tanta maldade no mundo? Nestas condições não podia mesmo ser diferente. Se o cristão é obrigado a arrancar ao vizinho o pão que necessita, para não falar na manteiga, e se até para o indispensável o irmão tem de lutar contra o irmão, é natural que os sentimentos nobres desapareçam do peito humano. Mas vamos supor que amar ao próximo não fosse nada mais que servir o freguês. Logo o Novo Testamento fica fácil de entender...”. BRECHT, Bertold. A Santa Joana dos Matadouros. Trad. de Roberto Schwarz. Vol. 4 do Teatro Completo. Rio de Janeiro: Paz e Terra, 1990, p. 50-51.

${ }^{14}$ Mateus, 4, 8 e 9. Tradução de João Ferreira de Almeida. Rio de Janeiro: Sociedade Bíblica do Brasil, 1962.
} 
O que possa restar do domínio do coletivo, desalentado, em solidão, não é como a chuva ${ }^{15}$; caudaloso dilúvio, sem arca à vista, sem estio, o céu como um teto de águas pesadas, cor de chumbo ${ }^{16}$.

Quantos de nós já não nos esquecemos de que a música é um trabalho eminentemente coletivo? O povo cultivando a essência da língua; o artista colhendo-a re-elabora combinações e sínteses em diálogo com os mestres que vieram antes, comunicando de volta à sociedade como cristalizações poéticas que se transmutam lentamente pela voz do povo em essências de língua que o artista, como um dentre eles, recebe e re-compõe através da imaginação insuflada pela tradição estabelecida pelas grandes obras, até que o capitalismo em sua empresa de destruições de tudo o que não se metamorfoseie em dinheiro, espatifou o elo da corrente.

Não há língua musical erudita em Mahagonny. E não havendo, como haveria de haver entendimento neste campo, entre mahagonnenses? E como poderia ser de outro modo no âmago de um sistema de organização social, em exercício exaurido, que traz para o MERCADO, assim como o sacerdote trazia para o altar-mor, as decisões todas da existência humana? O destino não só das almas, mas dos corpos que abrigam as almas. Até a educação das mentes que fazem corpo com as almas? E a saúde dos corpos de almas cujos espíritos o mercado já dispõe? Oh! Mercado-todo-poderoso, não tenha piedade de nós.

Em violências, tornamo-nos os melhores. Mais sábios em teorias incontaminadas pelas práticas, puras teorias, esculpidas em impermista ideologia, verdadeiramente necessárias para este adorável mundo nosso. Mais vividos nas práticas de convivências, de conveniente e pacífica coexistência com o desemprego, a fome de milhões, a miséria mais aparente, a desolação, as crianças abandonadas. Mais pedagógicos na administração de nossas artes que tão bem refletem as infinitas gamas do cotidiano. E esses shoppings, que tais os palácios da antigüidade, em paisagens urbanas futuras darão testemunho de nós. Orarão por nós.

Freqüentemente escutamos a tacha de alienada atirada sobre a música erudita capitalista contemporânea. Incorreta. Impossível que alguém, com o fito de escapar do real, entregue-se a esta música. Ela própria é de um realismo

\footnotetext{
${ }^{15}$ RILKE, Rainer Maria. A Solidão.

${ }^{16}$ FERREIRA, Dédalos. A Arca.
} 
extravagante, imane, horrendo, medonho, terrível. Aflitiva. Dolorosa, até. Tanto que a isso se deve, em parte, o pouco uso que dela se faz em nosso meio. As mínimas dissimulações só sublinham a regra. Porém, pode suceder de os horrores da música realista contemporânea serem mais suportáveis para algumas pessoas do que o próprio mundo que ela reflete, e que assim, ocasionalmente, sirva de evasão ${ }^{17}$. Não é a música capitalista contemporânea que é alienada, não. Ela espelha a insanidade mental de um modo de produção que dirige e organiza as relações entre os homens, a um grau de alienação tal, que problemas cruciais para a sobrevivência dos homens, como o desemprego, o amor, a alimentação, saúde, moradia, educação, são entregues nas mãos do divino MERCADO. As “soluções” dos problemas têm que ser convenientes - antes de qualquer outra coisa - ao mercado onisciente. Ele é o dinheiro e tem dono. É o poder, a força, a justiça, e que podendo tudo comprar, todas as coisas se tornam parte de suas qualidades. Portanto, a música como reflexo da doença mental do mundo, do tresvario social em todas as suas variantes e dimensões, patológicas, explica - em parte - o enorme sumário de suas diversificações na atualidade. Não é, pois, a música (realista) burguesa que é alienada, mas sim o mundo burguês, insensato, temerário, desvairado, furioso, horroroso, com suas glórias e violências.

Os humores que o universo social burguês inspira, gravitam em torno de variações dos sentimentos de angústia, de depressão, de desespero, de tristeza. A música contemporânea burguesa pode soar estranha (como soa o palavreado de uma língua desconhecida), esquipática, anômica, mas seu tom emocional e gestualidades revelam-se extremamente característicos do mundo do qual provêm. Não é, neste caso, a ausência de língua comum que embaçaria o espelhamento do mundo real. No campo da figuração, da representatividade da loucura de um mundo capitalista, a a-direcionalidade harmônica, a constância rebarbativa da dissonância, a desorientação dos saltos em zig-zag pelo campo de tessitura, soam como expressões adequadas. A oposição de fase entre produção e consumo sinaliza ausência de língua falada, mas não alienação da realidade. Se obedece, como dissemos, à lógica da realidade psíquica do compositor, então, pen-

\footnotetext{
17 “Às vezes Schöenberg acha que suas obras soam horríveis na realidade. Depois de escrevê-las resulta difícil compreendê-las, e tem que estudá-las com grande esforço”, conta Brecht em seu diário de trabalho, a propósito de uma visita ao compositor, datada de "fins de outubro de 1944".
} 
sando melhor, é possivelmente mais resultante da carência de língua social viva do que apenas da psicopatologia (particular) do compositor; pois o individualismo intransigente do qual padece o artista é doença social generalizada, e afeta a sociedade inteira, independentemente das artes e manhas que pratiquem seus membros. Certamente que as classes de menor poder aquisitivo são mais infensas à moléstia, e que só o repúdio sistemático da exploração do homem pelo homem, o sentimento e a prática da solidariedade, podem defender o indivíduo contra o mal, à maneira de uma vacina. Mas lembremos: não é permanente, e muito menos obrigatória.

\section{Estranhar o que não for estranho}

O que resta de música erudita na sociedade capitalista deveria constituirse em escândalo suficiente para admoestar sobre o estado precário da cultura burguesa, como um todo. A música do passado, repassada de enganos, e a música do presente bloqueada pela ausência de língua e obrigadas as vozes ao embaraçamento de articulações indistintas, privadas, anômicas. Escrevo sobre música, que é matéria de discussões neste trabalho, mas brechas estão fendidas em vários campos do conhecimento.

Deveria ser visto como escândalo a aceitação (a simples acolhida) da inclusão da MÚSICA ERUDITA CONTEMPORÂNEA como item cultural vivido pela sociedade capitalista. A aceitação do estado em que se encontra a música erudita na sociedade burguesa, como coisa natural, significa (no fundo) legitimar, aprovar um modo de produção incompatível com o espírito de uma arte que resiste a se tornar mercadoria. A aceitação da vida musical erudita no capitalismo significa que pouco me incomodo se a música é ou não compreendida, contanto que circule como uma, entre tantas outras mercadorias, e que, ainda por cima, sirva como "boa imagem” e música incidental para o drama malaventurado vivido (morrido, seria mais apropriado) pelos homens (em especial os que deixam a pele no curtume) sob o jugo do MERCADO.

Com a música do passado, Midas logrou o milagre de três vírgula tanto por cento relativos à soma global do produto da indústria fonográfica mundial. Isso não deveria ser motivo de júbilo, visto que as mercadorias musicais postas à venda encontram-se esvaziadas de significados, tal o estado de indigência cultural do Estado a serviço da economia de mercado. Convém recordar que a lenda conta que Midas tomou um pedaço de pão para comer e à boca chegou-lhe ouro: passou fome; quis água para beber e o ouro não desceu pela garganta: 
passou sede; quis ouvir música, e o ouro engastalhou-se-lhe nos ouvidos, ensurdecendo-o. Ao cérebro, intoxicou-lhe o espírito, embrutecendo-o.

Aceitar a inclusão da música erudita no capitalismo é compactuar com o estado das coisas, com o escândalo. A aceitação da prática da música erudita no capitalismo é sintoma de recepção (consciente ou inconsciente) da ideologia que emana deste Estado. Muitos são levados a levar a sério a práxis musical erudita capitalista, por causa de algumas migalhas que, caindo da mesa de seus senhores, são injetadas em festivais, no ensino, na sobrevivência de instituições sinfônicas, de espetáculos operísticos, porém não passam de finíssima camada de folheação a ouro (que escondem a ausência de linguagem viva, a ignorância), folheado que não resiste ao arranhão de unha de uma donzela. A supervivência agonizante do movimento editorial é mínima, quase nula. Os exemplares de gravações - não mascaremos - circunscritos à realidade dos 3,8\% do total da produção fonográfica mundial.

Estranhar o que não for estranho:

Não aceiteis o que é de hábito como coisa natural, pois em tempo de desordem sangrenta, de confusão generalizada, de arbitrariedade consciente, de humanidade desumanizada, Nada deve parecer natural. ${ }^{18}$

A música, para ser compreendida, requer anos e anos de trabalho intelectual profícuo, de prática, tudo implicando elevado custo e, sobretudo, de disponibilidade de tempo. TIME IS MONEY. Tempo que no capitalismo - deve ser desviado dos objetivos de desenvolvimento da capacidade de compradores profissionais em tempo integral; tempo que o acumulador de capital não desperdiça; tempo de exaustão para ouvidos atroados por máquinas e cultivados por canções de mercado (entre as despelações) ${ }^{19}$.

\footnotetext{
${ }^{18}$ Nada é impossível de mudar, poema de Bertolt Brecht, tradução de Edmundo Moniz. Antologia Poética - Bertolt Brecht. Rio de Janeiro: Elo Editora e Distribuidora LTDA, 1982. 19 “Ao trabalhador lhe é concedido que tenha só de que viver e queira viver só para ter”. MARX, Karl. Oekonomisch - Philosophische Manuskripte. Op. cit.
} 
A música, transformada em mercadoria, é mercadoria impertinente. A música, como mercadoria, faz exigências intelectuais de alta monta e gravidade, tanto devido à sua especificidade lingüística, quanto por sua história, o que não se ajusta ao alcance ideológico do capitalismo. "Se um produto fizer exigências, o consumo será menor”, disse prof. Gino Giacomino. E menor não quer (sequer) dizer que será consumido "por homem artisticamente educado".

Outro fator não menos importante, com respeito à resistência da música a se transformar em mercadoria, é a insofismável ignorância do público diante da densa complexidade do código de uma língua que não fala e que estranha. A música erudita - e muito especialmente a música contemporânea -, como mercadoria, é produto harto exigente que não encontra terreno propício em nosso modo de produção.

"Dom Quixote já pagou pelo erro de acreditar que a cavalaria andante seria igualmente compatível com todas as formas econômicas da sociedade”20.

Vislumbre-se o homem ocupado com o espírito, vivenciando as artes, deleitando-se com os testemunhos da capacidade criadora humana, e não diuturnamente alimentando, edificando o instinto de propriedade ${ }^{21}$, insaciável, à mercê da engenharia da obsolescência planejada.

"Se se pressupõe o homem como homem, e sua relação com o mundo como uma relação humana, só se pode trocar amor por amor, confiança por confiança, etc. Se se quiser gozar da arte, deve-se ser um homem artisticamente educado"22.

\footnotetext{
${ }^{20}$ MARX, Karl. Manuscritos Econômico-Filosóficos. Seleção de José Arthur Gianotti, tradução de José Carlos Bruni para o vol. XXXV de Os Pensadores. São Paulo: Abril S.A. Cultural e Industrial, 1974.

21 “A coragem de constatar que a propriedade privada pode bem estar inscrita em nossos costumes, pode bem estar escrita também no Código Civil, mas que não está nem em nosso código genético, nem nos Evangelhos aos quais se referem freqüentemente os bem-nutridos da moral dita Judaico-Cristã”. LABORIT, Henri. L'agressivité détournée. Paris: Union Générale d’Éditions, 1970, p. 45.

${ }^{22}$ MARX, Karl. O Capital. $3^{\text {a }}$ ed. Volume I, Livro Primeiro. Tradução de Régis Barbosa e Flávio Kothe. São Paulo: Editora Nova Cultural Ltda., 1988, nota 33 à p. 77.
} 
Só quando o homem se reorganizar socialmente, de modo a sublimar o ego até à abrangência dos outros, vivendo, pois, uma nova dimensão ideológica, só então uma arte NOVA será possível.

Asfixiados pelo capitalismo, só temos sido capazes de renovações de aspectos secundários em nossas manifestações artísticas. Diferentes "formatações" é o que temos conseguido para o mesmo velho escrito. O que obtemos, logo proclamamos - com insistência - que se trata de NOVA ARTE. E por força de tanto repetir é que alguns mais crédulos terminam por abonar.

Até que uma sociedade nova, SOLIDÁRIA, possibilite o surgimento de uma arte nova, socialmente necessária, a partir do aprofundamento espiritual que a energia transformadora (coletiva) propicie; até lá, aqueles que não tenham percebido isto, estão, desde já, condenados aos desregramentos do solipsismo mais cruel.

Solilóquio, quase sempre de maneira desordenada, pois que o senso de ordem também fica confundido quando o individualismo alucinante do capitalismo torna-se a medida de todas as coisas. De forma ordenada, poucos os solilóquios.

Infelizes soliloqüistas. Todos. Tanto aqueles que estão conscientes, quanto os que ignoram que a arte que praticam faz corpo pesado com a degenerescência moral: sólida, compacta, veloz em sua queda, descendo vertiginosa, tão baixo, que ergue alto o solipsismo.

Solo.

Solitude.

Solinhar - seguindo à risca o risco (ideológico), absurdo, de uma economia falida.

Soluços no sólio onde o solitário que se pensa rei.

Acabo de ler (para a devida revisão) a "prova” deste trabalho. A frase final, revi com os olhos da memória: uma imagem de Georges Rouault que vem a calhar, aqui. Vou à estante pegar o livro onde a gravura se encontra e pedirei ao caro Zeron que consiga reproduzi-la para esta publicação como ponto final. Vale 


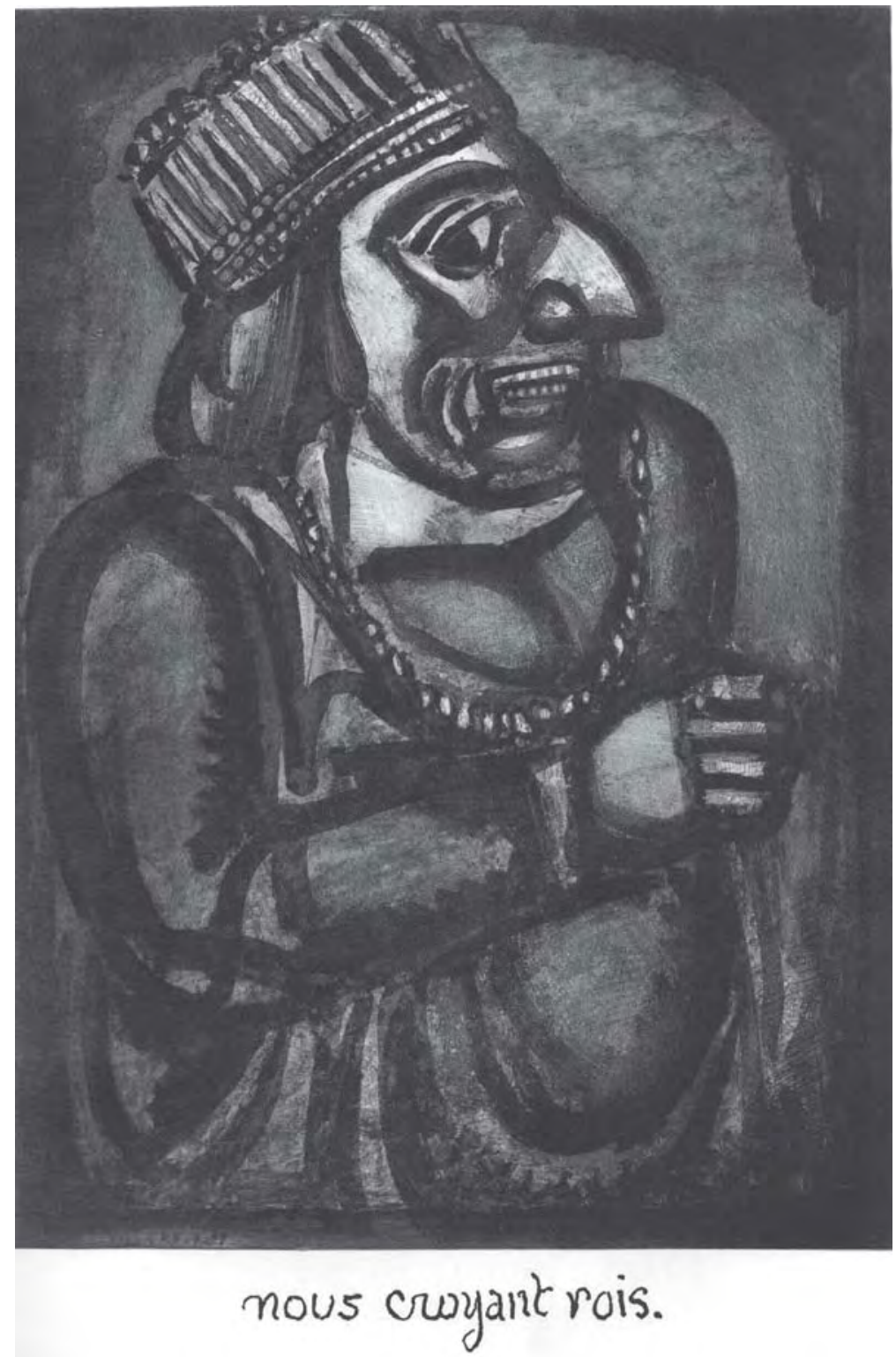

Georges Rouault, “Nous croyant rois” (“crendo-nos reis”) 